\title{
The Relationship between Perceived Social Support and Organizational Commitment Levels of Primary and Secondary School Teachers
}

\author{
Sema Karaçoban Tuna ${ }^{1}$, Hüseyin Aslan ${ }^{2, *}$ \\ ${ }^{1}$ ICT Teacher, Ministry of National Education, Turkey \\ ${ }^{2}$ College of Education, Ondokuz Mayis University, Turkey
}

Copyright $\bigcirc 2018$ by authors, all rights reserved. Authors agree that this article remains permanently open access under the terms of the Creative Commons Attribution License 4.0 International License

\begin{abstract}
The aim of this research is to investigate the relationship between perceived social support levels and the organizational commitment of the teachers working in state primary and secondary schools in Atakum, Canik, İlkadım and Tekkeköy districts of Samsun in Turkey in the academic year of 2014-2015. The research used relational search model and employed to collect data by using "Personal Information Form", "Organizational Commitment Scale" developed by Balay [1] and "Perceived Social Support Scale" by Çivilidağ [2]. Some important results of this research are: (1) there is a meaningful, positive and low-level relation between perceived social support level and organizational commitment; (2) perceived social support explains 3\% of the change in organizational commitment; (3) teachers have received most of the help from their husband or wife and obtained least help from their students among the sub-dimensions of perceived social support; (4) teachers have the strongest commitment to the internalization dimension among the organizational commitment sub-dimensions.
\end{abstract}

Keywords Organizational Commitment, Perceived Social Support, Primary and Secondary School, Teacher

\section{Introduction}

Organizations as a social system could keep on their existence as long as they accomplish three general aims such as making profit, serving the community and being persistent and specific aims such as employing, leading to being produced of a service or product in sector, innovating and increasing its reputation. To accomplish these goals, organizations primarily should be successful in some points like satisfying individual needs of employees, providing and maintaining their organizational commitment by ensuring job satisfaction [3-6]. Organizational commitment which is vital for organizations is based upon the unity of individual and organizational goals and being accomplished these goals. Thus, employees, who are deeply committed to their organizations, perceive themselves as an necessary part of the organization, satisfy their sociological and physiological needs, believe that they will be able to achieve their own personal aims through organizational aims, are more productive than the others and become much more integrated to organization and its values $[5,7,8$, 9].

The level of organizational commitment is dependent on whether organizational aims are correspondence to employees' norms and values; whether the individual needs are fulfilled [10]. Individuals primarily need economic power and social interaction. Spending time in a successful organization, namely work life enables the individual to improve himself/herself in the matters of fulfilling their basic needs, increasing their self-confidence by creating and producing and gaining others' appreciation and respect. Besides it gives the individual opportunities for fulfilling the needs [11].

Supportive relationships established in work life, where the individual spends about one-third of his/her life, positively affect cooperation among friends, communication in working groups, and feeling of being esteemed to him/her, job satisfaction and motivation. It is seen that the individuals who feel someone love him/her rely on his/her organization and get happier, more productive and successful and more satisfied with working groups and more loyal to organization and their work [12-14]. Because the individuals' communication with colleagues and manager whom they spend time together and perceived social support that means how the individual has been perceived by the others are very important to 
overcome the problems which they face in their work life and to increase their motivation and performance $[15,16]$.

On the other hand, the support which the individual perceives from his/her private life environment (family, friends, relatives etc.) is a factor affecting performance in work life as the support which the individual perceives from the people in work environment $[15,16]$. Social support is defined as material and moral support which provide the individual to be able to cope with stress in need and support him/her struggling with difficult sides of life and protect him/her from negative situations and is provided by the sources of social support in the environment [17-19]. Sources of social support are classified as family, friend and partner (husband-wife, girlfriend or special person etc.) for private life and as the manager and colleagues who help the individual solve the problems at work for work life [20,21].

In the recent researches, many writers such as Coyne and Downey (1991); Ell (1996) and Hupcey (1998) have used perceived social support instead of social support and put emphasis on how the social support is perceived and interpreted by the individual rather than provided social support for the individual [22,23]. The terms of both organizational commitment and perceived social support draw attention as two significant subjects to be increased success and performance of all the organizations which is a social system and to be formed structure of the modern society. School is at the head of organizations where the effects of each of two terms are felt intensely because of its position as the most important building block of education system and having many social relationships. The most important and strategic component that will guide the education to accomplish its aims in school organization as a social system is teacher [24-26].

Forming of the future in this way that it will range up the society is possible by being accomplished the education system's special and general aims. It is dependent on that teachers struggle much more than expected as well [27]. On the other hand, although the importance given to the teaching and teaching profession increases day by day in our country, it is seen that the problems continue; as one of the most important reasons for the fall in the quality of education can be related with the level of commitment of teachers to the educational institutions they work [1]. The degree of organizational commitment seems to be crucial, as employees are self-committed to increasing the effectiveness of schools with complex, multidimensional nature having inherently abstract aims with various values from different dimensions such as academic, social, economic, political etc. [24, 27].

In this case, teacher's devotion to school, students, education and teaching activities, his profession and colleagues affects his/her performance and success. In other words, his/her organizational commitment, communication with colleagues, school administration, students and people in his/her private life (family, friends, relatives etc.) and level of sharing something with them and perceived support from them are very significant.

Education cannot be restricted within the realm of formal curriculum and formal rules but it encompasses the dynamics of teacher behaviors and attitudes emerged in the classroom and school environments [69]. Thus, teachers who exhibit low commitment may cause the education and teaching deviate from its aim by acting negative behaviors in school environment and negatively affect the students $[28,29]$. In addition to that, teachers who have inadequate perception of social support may experience stress, depression and lack of motivation and performance $[2,30]$.

Even the physical needs of the first step of the Maslow's hierarchy of needs are not met by the schools, and also the external awards provided by the management are not enough to provide satisfaction. Even though teachers are thought to be addressed by meeting their primary needs by lowering their living standards and secondly, the need for security can only be achieved by the retirement, teachers are looking for the higher need for love and belonging, the need for respect and the need for self-fulfillment. Therefore, teachers have an important place in addressing the need for social acceptance, love, respect and support in both work and private life $[2,28]$. Teachers who spend a great majority of their daily lives in school are in contact with administrators, other teachers, assistant staff, students and parents who make up the social environment in the schools. In this sense, Civilidag [2] classified the sources that teachers are influenced and receive social support; as work place friends, friends outside the workplace, spouse, parents and students. How teachers are perceived in these intensive communication networks; value, respect and support they take; the peacefulness level of their environment, make their relationships healthy and high quality, and affect their creativity, their productivity, their attitudes towards the school and their absenteeism.

When the related literature reviewed, it is seen that many researches are made to examine the relationships between organizational commitment and various variables in order to determine the factors, which will increase the organizational commitment in educational institutions. However, there were no researches that contain the relationship between perceived social support level and organizational commitment and find out the effect of perceived social support on organizational commitment in literature review. Thus, this research aims to find out the levels of perceived social support and organizational commitment and the relationship between the levels of primary and secondary school teachers who firstly guide to form the new generations and take responsibility to realize the expectations of education system.

\subsection{Organizational Commitment}

There are different definitions of organizational commitment that was examined in the book of 
"Organization Man" by Whyte in 1956 for the first time [31,32]. Wiener [33] expresses organizational commitment as organizational identity, loyalty values, duties, personal predisposition and personalized values, which are affected by organizational interventions and struggle for organizational aims. On the other hand, Becker, Billings, Eveleth and Gilbert [34] state that organizational commitment is a psychological attachment of employees to their organizations and is related to such desirable outcomes as job satisfaction, motivation and attendance. Besides, Schwenk [35] states it as a behavior, which encourages working for organization intensively. In general, organizational commitment can be defined as a term which perceives the organization as a whole and includes such behaviors as the individual's loyalty to organization, psychological and moral sharing in organization, preferring the organizations' goals to individuals' own goals, making efforts for the organization, being eager to continuation of organization membership $[1,7,10,36]$.

Employees those have high organizational commitment are more self-sacrificing than expected and are less disposed to absenteeism, being late and making the end of organization membership. For these reasons, it is seen that these employees' expenditures are lower. Besides it is pointed out that these employees are more willing, easy-going, productive and steady to perform their duties and more contributive to innovations and creativity $[1,37$, $38,39]$. Organizations and employees who have high commitment respond to customers' expectations ideally, so the service quality of organization increases. Being internalized of organization's mission and vision, motivation and forming of team spirit are connected to organization commitment [39-41]. There are different classifications of organizational commitment as well as definitions. Three of all classifications come to prominence: attitudinal commitment, behavioral commitment, multi-dimensional commitment. Attitudinal commitment refers to integration of organization with individual; behavioral commitment is a state that individual has to stay in organization because of her/his behaviors in the past; multi-dimensional commitment argues that individual can exhibit commitment to different parts of organizations in different levels $[32,42,43]$. In this research, organizational commitment is based on three separate dimensions of commitment that O'Reilly and Chatman argue. These are compliance, identification and internalization.

In compliance dimension, the first stage of organizational commitment, individual makes efforts for external rewards, not shared values, some gains and avoiding from punishments $[1,5,37]$. Individuals are not given the right to choose, and individuals have to work in an unsafe environment at this level [37]. At this dimension, which is reward-focused and expresses a superficial commitment, forced adaptation is aimed at reaching individual interests and achievements, while employees are less likely to remain in the organization $[5$, $36,37]$.

In identification dimension, the second stage of commitment, individual accepts organization's aims and values and is glad to be a membership of organization and to live according to beliefs and values of organization. In short, it is possible to define the commitment dimension as a commitment, which creates satisfaction in individual $[5,10,41]$. In the dimension of identification which is related to employees' desire to be close, employees are willing to make good relations with each other and with the group; it is peaceful in being in organization; which in turn affects organizational productivity positively [5]. In order to achieve the identification dimension, the performance and behavior of the employees must be approved and praised; but it is also possible that your attractiveness is easily lost. On the other hand, loyalty at this dimension, although it seems to be pleasing for the person, it also entails responsibility and cost $[1,41]$.

Internalization dimension, which is the last stage of commitment, refers to the compliance between organization and individual and it will come true if individuals' and organizations' values are the same [10, $37,44]$. This process, which is both more difficult and longer to achieve, is the form of commitment that organizations desire most. Because once the dimension of internalization is realized, new resources are not needed to influence the individual anymore, since s/he has adopted new attitudes, behaviors or ideas as if he belonged to himself/herself $[1,37]$.

\subsection{Social Support}

The basis of social support having a lot of definitions in literature is based on field theory that Kurt Lewin founded on psychological environment. Lewin defined life space as everything that influences an individual's behavior at any time and behavior as a change in psychological environment. He stated that developing desired behavior and removing undesired behavior in the individual was possible with changes in psychological environment and he pointed out that social support was very important [45-47].

Social support having a lot of definitions is defined by Cobb [48] as information leading the individual to believe that $\mathrm{s} / \mathrm{he}$ is loved, esteemed, and belongs to a network of mutual obligation. Thoits [49] stated that social support was a source used for coping with stress. In addition to the definitions, Shumaker and Brownell [50] pointed out that social support was an exchange of resources between two individuals perceived by the provider or the recipient to be intended to enhance the well-being of the recipient.

In other words, social support means that the individual is supported, loved, esteemed and respected by social environment and not being alone. Besides, it provides the 
individual help materially and mentally, develops self-respect, increases self-confidence and affects job and private life positively. Therefore; it is seen to be obligation for life $[16,19,51,52,53]$.

The individual begins to feel social commitment to his/her environment while s/he obtains support being needed. People with high social support, have high social commitment, so these individuals are really better to notice their needs, feelings, thoughts and cognitive processes like self-assessment and comparison and to develop empathy and not to have compliance problems [54-55].

People who provides social support; namely, the sources of social support are important as provided social support for individual. The sources of social support means the total of relationships that are affected by personal, environmental and social factors and help the individual cope with problems and stress factors. They vary from case by case $[2,16,56]$.

The sources of social support are classified as family, friend and partner (wife, husband, darling or private person) for private life and as colleagues and managers for work life $[20,21]$. Some written sources divide the sources of social support into two categories like informal and formal or organizational and personal. While provided social support in organization is material and informative, provided social support in private life (family, friends) is emotional [2, 16, 17, 57].

In recent years, perceived social support that means how social support is perceived and is interpreted by the individual has been used instead of social support [22, 23]. Some researchers point out that perceived social support is more important for description of spiritual health [18].

The concept of perceived social support is not only important for every individual in society but also important for educational institutions; attention has been drawn to the fact that educational workers who lack support and are likely to encounter many different problems [58].

As a matter of fact, the teachers who are appreciated, encouraged by the school management; who are supported by colleagues in solving their professional and personal problems; helped by the parents to cope with student problems; who felt that they are good teachers by their students; who work in schools where the emotional connection is intense and a collaborative atmosphere is getting higher job performances, creativity and job satisfaction. Otherwise, teachers experience a sense of failure, unable to get their job done, become intolerant, they are angry and insensitive, have stress and anxiety. All of this affects the quality of education negatively $[15,30]$, because the personalities and mental health of teachers, as one of the most important elements of education, are as important as academic knowledge [2].

In this research, it is seen that the teachers who cannot get enough support from the school environment and the environment, the intense stress they experience, push them to loneliness and decrease their motivation; social support seems to be an important element in order to avoid these negative situations and to restore morale [30, $52]$.

\section{Aim of This Research}

The aim of this research is to investigate the relationship between perceived social support levels and the organizational commitment of the teachers working in state primary and secondary schools in Atakum, Canik, İlkadım and Tekkeköy districts of Samsun in Turkey. To achieve this aim, researcher has identified the following research questions:

1. What are the levels of perceived social support of the teachers working in primary and secondary schools in sub-dimensions of "husband-wife, parents, colleagues, friends and students"?

2. What are the levels of organizational commitment of teachers working in state schools in sub-dimensions of "compliance, identification and internalization"?

3. Is there a significant relationship between perceived social support levels and the organizational commitment of those teachers?

4. Is perceived social support level of those teachers one of predictors of their organizational commitment?

\section{Material and Methods}

\subsection{Research Model}

This research aims to find out the relationship between perceived social support levels and the organizational commitment of the teachers, who are working in state primary and secondary schools. It is a descriptive study used relational screening model. Relational screening model is defined as research model that aims to determine the existence and level of covariance among at least two or more variables [59].

\subsection{Population and Sample}

The population of this research consists of teachers working in public elementary schools (primary and secondary school) in Atakum, Canik, İlkadım and Tekkeköy districts of Samsun in Turkey during the period of 2014-2015 Academic years. Due to the abundance of the population of the research in number and the limitedness of time and economy, multi-stage sampling is used. The perceptions of classroom teachers' organizational commitment level to their institution do directly affect the 
teaching process. It is thought that class teachers are the most effective elements in shaping future generations According to Marbouti (2015) it was concluded that the higher the teachers' perceived autonomy, self-efficacy, and vocational social support received were, the better their performance in solving the problems that they encounter in their classrooms was. . Therefore, primary school teachers were selected as the sample in this study. Furthermore, the student population dealt with primary school teachers are more homogenous comparing to high schools, therefore it is more easy to investigate the real relationship between perceived social support and organizational commitment levels of primary and secondary school teachers by disregarding other effects such as department, branch etc.

In the first stage, the population of research is divided into four stratums (İlkadım, Canik, Tekkeköy ve Atakum) with stratified sampling. Stratified sampling is a method of sampling that researcher divides the overall population into different subgroups or stratums and aims to be represented the sampling in the overall population [60]. Then, it was calculated how many schools would be included to sampling by considering the numbers of school in districts and it was based on nearly $25 \%$ of the numbers of school in districts while calculating. While determining the numbers of school, different stratums as primary and secondary school weren't formed because of uncertainty of transformations of primary and secondary schools in mentioned districts. Therefore; the numbers of school in the sampling of research were determined to be $\% 25$ of the numbers of all public primary and secondary schools in each district. From this point of view, the sampling of research consists of 11 of 42 schools in Atakum, 14 of 55 schools in Canik, 13 of 52 schools in İlkadım and 12 of 46 schools in Tekkeköy.

In the second stage of sampling, simple random sampling was used. Simple random sampling is a type of sampling that each individual or group has the same probability of being chosen at any stage during the sampling process. The best way to choose a representative sampling is random sampling [60]. According to this, it was determined which schools and teachers in these schools would be included to sampling from each district with the technique of simple random sampling. For this purpose, surveys were delivered by hand to 739 teachers working in 50 schools that were chosen randomly and 712 surveys got back. 20 surveys weren't evaluated to not be filled according to survey instructions. As a result, the sampling of research consists of 692 teachers working in 50 public elementary schools.

It is seen in this study group that \%55.1 (381) of teachers are female, $\% 44.9$ (311) of them are male, \%17.9 (124) of them are 23-30 years old, \%43.1 (298) of them are $31-40$ years old, $\% 30.8$ (213) of them are 41-50 years old, \%8.2 (57) of them are over 51 years old, \%84.4 (584) of them are married, \%15.6 (108) are single, \%43.2 (299) of them are primary school teachers, \%56.8 (393) of them are branch teachers, \%11.4 (79) of them have length of service for $1-5$ years, \%20.8 (144) of them have length of service for 6-10 years, \%23.3 (161) of them have length of service for $11-15$ years and $\% 44.5$ (308) of them have length of service for over 16 years.

\subsection{The Data Collecting Tool}

The data collecting tool used in this research consists of three sections. Personal information form takes part in the first section, organizational commitment scale takes part in the second section and perceived social support scale takes part in the third section. Personal information form includes some variables like gender, age, branch, and marital status, the length of service in profession and the length of service in school.

\subsubsection{Organizational Commitment Scale}

In the second section of research, the data are collected through "Managerial Effectiveness Scale" developed by Murry (1993), and then translated into Turkish by İra and Şahin (2010) and through "Organizational Commitment Scale" developed by Balay (2000). In the second section of research, "Organizational Commitment Scale (OCS)" developed by Balay [1] was used. OCS that aims to measure the degree of integration of organization with individual and is inspired by O'Reilly III and Chatman's classification consists of three dimensions as compliance, identification and internalization. There are totally 27 items in this scale: 8 items in compliance dimension, 8 items in identification dimension and 11 items in internalization dimension.

In the compliance section, "I think I was mistaken in my decision to work in this school.", "My work and my savings prevent me from leaving this school.", "I believe that my success in the success of the students is limited to the teaching hours." I am having difficulty in adjusting to the school "," I am sleeping because I have to comply with the rules of this school. "," I feel that my enthusiasm for working in this school is decreasing day by day. " "I am proud to be a member of this school," "I feel that this school gives me the opportunity to follow changes and innovations in my profession.", "This school has given me the highest performance " "I think this school provides a suitable environment for education and training activities."," I often go out of school with my colleagues. ", "I prefer to work in this school if I work somewhere else, " " I believe in my ability to perform at the highest level in this school. " In the internalization section, there are items like "I make an effort beyond my expectations for my school's success", "I really think this school is going to come true", "I perceive the school problem as my own problem", " "' I consider my school's priorities to be my own priorities, "' I consider it a duty to act in accordance with the interests and expectations of my school. "," I feel praised as I praise my school. "" I enjoy teaching "," I 
make all kinds of sacrifices for my school's benefit. "

This scale prepared in five Likert type scale consists of choices as "disagree strongly" (1), "agree slightly" (2), "agree moderately" (3), "agree mostly" (4), "agree completely" (5). High point refers to high organizational commitment and low point refers to low organizational commitment [1]. Balay [1] has found Cronbach-Alpha reliability coefficient of the data collecting tool .79 for compliance dimension, .89 for identification dimension, .93 for internalization dimension. In this research, Cronbach-Alpha reliability coefficient was calculated .78 for compliance dimension, .86 for identification dimension, .92 for internalization dimension.

\subsubsection{Social Support Scale}

In the third section of research, perceived "Social Support Scale (PSSS)" developed by Çivilidağ [2] was used. It was formed with five questions and five support sources by Çivilidağ [2] and an industry psychologist aiming at measuring the affective dimension of social support by the help of industrial psychologist. The scale aims to determine social support that teachers perceive from colleagues, wives or husbands, parents, friends outside work and students and because of that, it includes five sub-dimensions. There are items in the scale like "How comfortably do you share this happiness with the people in the categories below when you hear a praise or appreciation for your well-being and you feel happy about it?". "You made a mistake when doing your job, and if you are sad about it, how comfortable do you share this with the people in the following categories?" "How easily do you share the tension in your work with the persons listed in the following categories?" "How easily do you share this with people in the following categories when you make an important decision about your business, such as moving to a new job or starting a new project?" "How easily do you share the difficulties of your work and the problems you are experiencing with the persons listed in the following categories?"

This scale prepared in five Likert type scale consists of choices as "never share easily" (1), "not share easily" (2), "undecided" (3), "share easily" (4), "share very easily" (5). Çivilidağ (2003) has found the reliability coefficient Cronbach-Alpha rate of the data collecting tool .89 for "colleagues" sub-dimension, .92 for "wife or husband" sub-dimension, .93 for "parents" sub-dimension, .91 for "friends outside work" sub-dimension, .87 for "students" sub-dimension and .92 for all the scale. In this research, the reliability coefficient Cronbach-Alpha rate was calculated .85 for "colleagues" sub-dimension, .90 for "wife or husband" sub-dimension, .93 for "parents" sub-dimension, .89 for "friends outside work" sub-dimension, .86 for "students" sub-dimension and .93 for all the scale.

\subsection{The Data Analysis}

SPSS 17.0 was used to be analyzed the data obtained in the study. Arithmetic mean and standard deviation were used to determine perceived social support levels and the organizational commitment levels of the teachers, Pearson product moment correlation coefficient was used to determine the relationship between perceived social support level and the organizational commitment of the teachers and simple linear regression was used to predict the effect of perceived social support on organizational commitment. Value ranges were used to classify teachers' answers given for scale items. The levels and point ranges of the scales used in the research are given in Table 1.

Table 1. The levels and point ranges related to OCS and PSSS

\begin{tabular}{|c|c|c|c|c|c|}
\hline $\begin{array}{c}\text { Organizational } \\
\text { Commitment }\end{array}$ & Scale & $\begin{array}{c}\text { Perceived Social } \\
\text { Support }\end{array}$ & Scale & Point Ranges & Levels \\
\hline Disagree strongly & $(1)$ & Never share easily & $(1)$ & $1.00-1.79$ & Low Level \\
\hline Agree slightly & $(2)$ & Not share easily & $(2)$ & $1.80-2.59$ & Moderate Level \\
\hline Agree moderately & $(3)$ & Undecided & $(3)$ & $2.60-3.39$ & High Level \\
\hline Agree mostly & $(4)$ & Share easily & $(4)$ & $3.40-4.19$ & \\
\hline Agree completely & $(5)$ & Share very easily & $(5)$ & $4.20-5.00$ & \\
\hline
\end{tabular}




\section{Findings}

The first sub-problem of research is determined as "What are the levels of perceived social support of the teachers working in public elementary schools (primary and secondary school) in sub-dimensions of "husband-wife, parents, colleagues, friends outside work and students ?" The levels of perceived social support of teachers are indicated in Table 2.

Table 2. The Levels of Perceived Social Support of the Teachers in Public Elementary Schools

\begin{tabular}{|c|c|c|c|}
\hline Factors & $\mathrm{n}$ & $\bar{X}$ & Ss \\
\hline Colleagues & 692 & 3.69 & 0.89 \\
\hline Husband-Wife & 584 & 4.35 & 0.79 \\
\hline $\begin{array}{c}\text { Parents (Father and } \\
\text { Mother) }\end{array}$ & 660 & 3.74 & 1.15 \\
\hline Friends outside work & 692 & 3.67 & 0.99 \\
\hline Students & 692 & 2.66 & 1.13 \\
\hline Total & & 3.59 & 0.73 \\
\hline
\end{tabular}

When analyzed Table 2, it is pointed out that teachers have gotten the most of the support from their husband or wife with $\bar{X}=4.35$ (High Level) and gotten the least support from their students with $\bar{X}=2.66$ (Moderate Level) among the sub-dimensions of perceived social support of teachers. It is found that the total mean score is $\bar{X}=3.59$ (High Level).

The second sub-problem of research is determined as "What are the levels of organizational commitment of teachers working in public elementary schools in sub-dimensions of compliance, identification and internalization?" The levels of organizational commitment of teachers are indicated in Table 3.

Table 3. The Levels of Organizational Commitment of Teachers in Public Elementary Schools

\begin{tabular}{|c|c|c|c|}
\hline Factors & $\mathrm{n}$ & $\bar{X}$ & Ss \\
\hline Compliance & 692 & 1.80 & 0.69 \\
\hline Identification & 692 & 2.98 & 0.88 \\
\hline Internalization & 692 & 3.43 & 0.82 \\
\hline Total & & 2.81 & 0.49 \\
\hline
\end{tabular}

It is come to this conclusion that teachers have the highest commitment to the internalization dimension with the score $\bar{X}=3.43$ (High Level) among the organizational commitment sub-dimensions and the lowest commitment to the compliance dimension with the score $\bar{X}=1.80$ (Low Level) among the organizational commitment sub-dimensions. It is found that the total mean score is $\bar{X}$ $=2.81$ (Moderate Level).

The third sub-problem of research is determined as "Is there a significant relationship between perceived social support levels and the organizational commitment of the teachers working in public elementary schools?" The results of correlation analysis for the relationship between perceived social support levels and the organizational commitment of the teachers are indicated in Table 4.

Table 4. The Results of Correlation Analysis for The Relationship Between Perceived Social Support Levels and The Organizational Commitment of The Teachers

\begin{tabular}{|c|c|c|c|}
\hline \multicolumn{2}{|c|}{ Variables } & $\begin{array}{c}\text { Organizational } \\
\text { Commitment }\end{array}$ & $\begin{array}{c}\text { Perceived Social } \\
\text { Support }\end{array}$ \\
\hline \multirow{2}{*}{$\begin{array}{c}\text { Perceived Social } \\
\text { Support }\end{array}$} & $\mathrm{r}$ & $.165^{* *}$ & 1 \\
\cline { 2 - 4 } & $\mathrm{p}$ & .000 & \\
\hline \multirow{2}{*}{$\begin{array}{c}\text { Organizational } \\
\text { Commitment }\end{array}$} & $\mathrm{r}$ & 1 & $.165^{* *}$ \\
\cline { 2 - 4 } & $\mathrm{p}$ & & .000 \\
\hline
\end{tabular}

$* * \mathrm{p}<.01$

As seen in Table 4, It is found that there is a meaningful, positive and low level relation between perceived social support level and organizational commitment $(\mathrm{r}=.165$; $\mathrm{p}<.01$ ). According to this, the more perceived social support increases, the more organizational commitment increases.

The fourth sub-problem of research is determined as "Is perceived social support level of the teachers working in public elementary schools one of predictors of their organizational commitment?" The results of simple linear regression analysis for the regression of organizational commitment are indicated in Table 5.

Table 5. The Results of Simple Linear Regression Analysis for the Regression of Organizational Commitment

\begin{tabular}{|c|c|c|c|c|c|}
\hline Variable & B & $\begin{array}{c}\text { Standard } \\
\text { Error }\end{array}$ & $\beta$ & $\mathrm{t}$ & $\mathrm{p}$ \\
\hline Constant & 2.416 & .093 & - & 26.053 & .000 \\
\hline $\begin{array}{c}\text { Perceived } \\
\text { Social Support }\end{array}$ & .111 & .025 & .165 & 4.385 & .000 \\
\hline $\mathrm{R}=0.165$ & \multicolumn{4}{|c|}{$\mathrm{R}^{2}=0.03$} & \\
\hline $\begin{array}{c}F(1-690)= \\
19.227\end{array}$ & \multicolumn{4}{|c|}{$\mathrm{p}=.000$} & \\
\hline
\end{tabular}

According to Table 5, the results of simple linear regression analysis made to find out in what way perceived social support predicts the organizational commitment indicate that there is a meaningful, positive and low level relation between perceived social support level and organizational commitment $\left(\mathrm{R}=0.165 ; \quad \mathrm{R}^{2}=0.03\right)$ and perceived social support is a significant predictor of the organizational commitment $(F(1-690)=19.227 ; p<0.05)$. Perceived social support explains $3 \%$ of the change in organizational commitment. Besides, it is seen again that perceived social support is a significant predictor of the organizational commitment $(\mathrm{p}<0.05)$ when analyzed the results of t-test related to the significance of regression coefficient. According to the results of regression analysis, the equivalence of regression predicting the organizational commitment is given below (Mathematical Model):

Organizational Commitment $=2.416+0.111$ Perceived Social Support 


\section{Discussion, Conclusions and Recommendations}

When analyzed the findings of the research, it is seen that teachers have received the most of the support from their husband or wife (High Level and received the least support from their students (Moderate Level). In general, it is pointed out that teachers have received support from their sources of social support at high level. Teachers have received the most support from their husband/wife and received the least from their students. This is consistent with the other research findings [2, 61]. It can be commented that married teachers share problems or good news in their schools with mostly their husband or wife rather than people around their environment. On the other hand, it is found that the level of perceived social support in students dimension is lower than other dimensions. This state can be explained that teachers do not share anything about them with students except for students' problems and happiness because of that age gap between teachers and students of elementary schools is much. Tasdan [62] research with primary school teachers came to the similar conclusion that teachers have received the least support from their students.

When analyzed the organizational commitment levels of elementary school teachers in these dimensions (compliance, identification and internalization), it seen that the commitment in compliance dimension is at low level, the commitment in identification dimension is at moderate level and the commitment in internalization compliance dimension is at high level. In compliance dimension, individuals think mostly their benefits (gaining an award, getting promotion, awarding with salary etc.), so the commitment in this dimension at high level is not a desired situation for quality of education and success of schools.

The commitment in identification dimension will occur if teachers internalize values and norms of school. Teachers will be happy and proud of working with their colleagues at the same environment and being a member of school. The commitment in internalization dimension that is the third one and is mostly preferred by schools occurs for congruence personal values and norms of teachers with the values and norms of school.

The findings of this study also suggest that teachers have the lowest commitment to compliance dimension and the highest commitment to internalization dimension can be explained that teachers taking part in the research care the benefits of their schools much more than their own benefits. The results of researches conducted by Özkan [63], Erdaş [64], Kul [65], Uygur [66] and Yüce [67] are similar to the results of this study. Pearson product moment correlation analysis was made to determine whether there is a significant relationship between perceived social support levels and the organizational commitment of the teachers taking part in this research or not. In the result of analysis, it is determined that there is a meaningful, positive and low level relation between perceived social support level and organizational commitment of teachers working in elementary schools. It can be said that the more perceived social support increases, the more organizational commitment increases even if just a bit.

Even if the relationship between perceived social support and organizational commitment is not at high level, teachers who have someone supporting them and sharing with their problems at work or private life will gradually increase their own self-confidence, desire to continue working and making efforts for their schools when teachers face with negative circumstances. In the other words, it can be said that perceived social support at high level is an advantage. Erdogan at al., [68] have stated that perceived social support at high level will be able to take away expected negative situations if teachers have compliance to their schools at low level.

Simple linear regression analysis was made to predict the effect of perceived social support of teachers on organizational commitment to their schools. In result of analysis, it is found that there is a meaningful, positive and low level relation between perceived social support level and organizational commitment and perceived social support explains $3 \%$ of the change in organizational commitment. It can be said in this context that perceived social support is a significant predictor of organizational commitment. If perceived social support increases 1 unit, organizational commitment will increase 0.111 units and because of that, it is predicted that organizational commitment will change according to the intensity of perception if perceived social support of students' increases. Katz and Kahn (1966) pointed out that accepted supporting revealed individuals' potential in better way and was effective on their commitment [11].

This study suggests that the teacher training system should be re-arranged and those who are congruent with the aims and values of school should be encouraged to study education and hired as teachers. Also, individuals who are volunteer, eager to do this job, tolerant and have some special treats that are valuable for teaching should be offered to be teacher and some inventories should be fulfilled to find out physiological states while choosing the candidates of teachers.

Improvements in profession of teacher should be made by taking teachers' views, economical arrangements should be made and physiological support should be provided for teachers in need. Administrators should encourage communication among teachers, teachers' adaptation to school and should take some necessary precautions for being formed the environment of healthy communication. Besides, they should find physiological and moral factors to increase teachers' commitment to school. Similar researches can be conducted with teachers working in different provinces from different geographical 
regions and comparisons between regions can be made. The population of the research can be enlarged by adding private schools to research.

\section{REFERENCES}

[1] Balay, R. (2000). The organizational commitment of administrators and teachers in private and public secondary schools. Unpublished Ph.D. Dissertation. Ankara University, Social Sciences Institute.

[2] Çivilidağ, A. (2003). A Comprehensive analysis of job satisfaction, job stress and perceived social support between Anatolian high school teachers and private high school teachers. Unpublished MA Thesis. Istanbul University, Social Sciences Institute.

[3] Aras, A. (2012). Relations among mobbing levels, organizational commitment and job satisfaction of music teachers working in elementary schools. Unpublished Ph. D. Dissertation. Ankara Gazi University, Educational Sciences Institute.

[4] Bakay, E., Kurşunoğlu, A. \& Tanriöğen, A. (2010). Organizational commitment levels of elementary school teachers]. Pamukkale University, Journal of Education Faculty, 28 (2), 101-115.

[5] Güney, S. (Ed.). (2007). Management and organization. (2. Press). Ankara: Nobel Publishing House.

[6] Özden, Y. (2005). Handbook of education and school administration. (2. Press). Ankara: Pegem Academy Publishing House.

[7] Günce, S. (2013). Relationship between organizational justice and organizational commitment in primary schools. Unpublished MA Thesis. Şanlıurfa Harran University, Social Sciences Institute.

[8] Karataş, S. \& Güleş, H. (2010). The relationship between job satisfaction and organizational commitment of primary school teachers. Uşak University, Journal of Social Sciences, 3(2), 74-89.

[9] Koç, H. (2009). The relationship between organizational commitment and loyalty. Journal of Electronic Social Sciences, 8(28), 200-211.

[10] Balay, R. (2014). Organizational commitment of school administrators and teachers. (2. Press). Ankara: Pegem Publishing House.

[11] Çivilidağ, A. (2011). At the universities academics staff's mobbing, job satisfaction and perceived social support levels. Unpublished Ph.D. Dissertation. Konya Selcuk University, Educational Sciences Institute.

[12] Gider, Ö. (2010). A study based on levels of organizational commitment, organizational trust and job satisfaction of personnel at training and research hospitals. Journal of Management, 21(65), 81-105.

[13] Korkmaz, M. (2011). The effects of organizational climate and organizational health on organizational commitment in primary schools. Educational Administration: Theory and
Practice, 17(1), 117-139.

[14] Özgüven, İ. E. (2003). Industry psychology. (1. Press). Ankara: PDRem Publishing House.

[15] Altay, M. (2007). The relationship between occupational burnout and multidimensional perceived social support school administrators. Unpublished MA Thesis. Tokat Gaziosmanpaşa University, Social Sciences Institute.

[16] Torun, A. (1995). A study on the relationships among burnout, family structure and social support. Unpublished $\mathrm{Ph}$. D. Dissertation. Istanbul Marmara University, Social Sciences Institute.

[17] Bozkurt, Y. (2013). Teaching institution teacher's job satisfaction and social support of the relationship between perceived managers. Unpublished MA Thesis. Istanbul Maltepe University, Social Sciences Institute.

[18] Çakır, Y. \& Palabıyıkoğlu, R. (1997). A study on reliability and validity of the scale of perceived multidimensional social support and social support on teenager. Journal of Crisis, 5(1), 15-24.

[19] Okyayuz, Ü. H. (Ed.). (1999). Health psychology. (1. Press). Ankara: Turkish Psychological Association.

[20] Karasek, R. A., Triantis, K. P. \& Chaudhry, S. S. (1982). Coworker and supervisor support as moderators of associations between task characteristics and mental strain. Journal of Occupational Behaviour, 3(2), 181-200.

[21] Zimet, G. D., Dahlem, N. W., Zimet, S. G. v\& Farley, G. K (1988). The multidimensional scale of perceived social support. Journal of Personality Assessment, 52(1), 30-41.

[22] Eker, D., Arkar, H. \& Yaldız, H. (2001) Factor structure, validity and reliability of reviewed form of multidimensional perceived social support scale. Journal of Turkish Psyschiatry, 12(1), 17-25.

[23] Ünüvar, A. (2003). The effect of formal various perceived social support on the self-esteem and problem solving abilities of high school students at the age of fifteen to eighteen. Unpublished MA Thesis. Konya Selçuk University, Social Sciences Institute.

[24] Başaran, İ. E. \& Çınkır, Ş. (2013). Turkish education system and school administration. (4. Press). Ankara: Siyasal Press.

[25] Durak, S. (2009). The comparison of the levels of social support and work satisfaction of the teachers who work at anatolian high schools and public high schools. Unpublished MA Thesis. Istanbul Yeditepe University, Social Sciences Institute.

[26] Kartal, Ş. (2006). A comparative analysis of job satisfaction levels of in-field and out-of-field primary school teachers appointed in Nevşehir. Unpublished MA Thesis. Kayseri Erciyes University, Social Sciences Institute.

[27] Balay, R. (2007). Organizational commitment factors of elementary school teachers: A sample of Şanluurfa province. XVI. National Educational Sciences Congress, (September 5-7 2007, Tokat Gaziosmanpasa University.

[28] Celep, C. (2000). Organizational devotion in education and teachers. (1. Press). Ankara: An1 Publishing House. 
[29] Özkan, V. (2008). Organizational commitment levels of the class teachers who work in Sakarya province according to some variables. Unpublished MA Thesis. Sakarya Üniversitesi, Social Sciences Institute.

[30] Demirtaş, A. S. (2007). The relationship between perceived social support, loneliness and the coping stress levels of the students attending the 8th class in elementary schools. Unpublished MA Thesis. Ankara Gazi University, Educational Sciences Institute.

[31] Çöl, G. (2004). The concept of organizational commitment and its relationship with similar concepts, Retrieved March 3, 2015 from http://www.isguc.org/?p=article\&id=233\&cilt=6\&sayi $=2 \&$ yil $=2004$.

[32] Gül, H. (2002). Assesment and comparison of approaches of organizational commitment. Journal of Aegean Academic View, 2(1), 37-55.

[33] Wiener, Y. (1982). Commitment in organizations: a normative view. Academy of Management Review, 7(3), $418-428$.

[34] Becker, T. E., Billings, R. S., Eveleth, O. M. \& Gilbert, N. L. (1996). Foci and bases of employee commitment: implications for job performance. Academy of Management Journal, 39(2), 464-482.

[35] Schwenk, C. R. (1986). Information, cognitive biases and commitment to a course of action. Academy of Management Review, 11(2), 298-310.

[36] Akgül, Z. (2014). A study of the relations between organizational commitment and burnout according to mathematics teachers' perceptions. Unpublished MA Thesis. Sivas Republic University, Educational Sciences Institute.

[37] Balc1, A. (2003). Organizational socialization: Theory, strategy and tactics. (2. Press). Ankara: Pegem Publishing House.

[38] Durna, U. \& Eren, V. (2005). Organizational commitment in connection with three components of commitment. Journal of Dogus University, 6(2), 210-219.

[39] Sarıdere, U. (2004). Unpublished MA Thesis. Kocaeli University, Social Sciences Institute.

[40] Ağacık, K. (2011). The effect of the organizational climate on the organizational commitment in the private educational institutions in Kütahya. Unpublished MA Thesis. Kütahya Dumlupınar University, Social Sciences Institute.

[41] İnce, M. \& Gül, H. (2005). A new paradigm in administration: organizational commitment. (1. Press). Konya: Çizgi Press.

[42] Reichers, A. E. (1985). A review and reconceptualization of organizational commitment. Academy of Management Review, 10(3), 465-476.

[43] Varoğlu, D. (1993). Public sector employees' attitude, commitment and values to their jobs and institutions. Unpublished Ph. D. Dissertation. Ankara University, Social Sciences Institute.

[44] O'Reilly III, C. \& Chatman, J. (1986). Organizational commitment and psychological attachment: the effects of compliance, identification and internalization on prosocial behavior. Journal of Applied Psychology, 71(3), 492-499.

[45] Öner, U. \& Gümüş, A. (2000). Kurt Lewin and field theory, Lewin's child psychology. Ankara University, Journal of Educational Sciences Faculty, 1(33), 9-27.

[46] Şencan, B. (2009). Research of the perceived social support level by high school students and social self-efficacy expectation level according to some variable. Unpublished MA Thesis. Adana Cukurova University, Social Sciences Institute.

[47] Yıldırım, İ. (1997). Scale development, reliability and validity on perceived social support. Hacettepe University, Journal of Education Faculty, 13(1), 81-87.

[48] Cobb, S. (1976). Social support as a moderator of life stress. Psychosomatic Medicine, 38(5), 300-314.

[49] Thoits, P. A. (1995). Stress, coping and social support processes: where are we? what is next? Journal of Health and Social Behavior, 35(1), 53-79.

[50] Shumaker, S. A. \& Brownell A. (1984). Toward a theory of social support: closing conceptual gaps. Journal of Social Issues, 40 (4), 11-36.

[51] Abay, A. (2009). The study of relation between mobbing and social support perceptions of teachers who work at primary schools]. Unpublished MA Thesis. Istanbul Maltepe University, Social Sciences Institute.

[52] Çankaya, İ. H. \& Tan, Ç. (2010). Relationship between schools based social support and stress according to teachers' view. Frrat University, Journal of Social Sciences, 20(2), 211-221.

[53] Yüncü, Z., Yıldız, U., Kesebir, S., Altıntoprak, E., \& Coşkunol, H. (2005). Assessment of social support systems of patients, those have the alcohol use problem. Journal of Addiction, 6(3), 129-135.

[54] Cirik, İ. (2010). Research conducted on 5th, 6th, 7th and 8th grade primary school students' perception of social support levels. Unpublished Ph.D. Dissertation. Istanbul Marmara University, Educational Sciences Institute.

[55] Tras, Z. \& Güngör, H. C. (2011). A qualitative study on social support and social connectedness issues in regard to university students of Turkish origin coming from European countries. Konya Selçuk University, Journal of Social Sciences Institute, 25(1), 262-271.

[56] Shook, S. L. \& Pugliesi, K. (1998). Gender, ethnicity and network characteristics: variation in social support resources. Sex Roles, 3(4), 215-238.

[57] Fındıkçı, İ. (1999). Personnel Management. (1. Press). İstanbul: Alfa Publishing House.

[58] Taşdan, M. \& Yalçın, T. (2010). The relationship between social support and organizational trust levels perceived by primary school teachers. Journal of Educational Sciences in Theory and Practice, 10(4), 2569-2620.

[59] Karasar, N. (2012). Scientific research methods. (22.Press). Ankara: Nobel Publishing House.

[60] Büyüköztürk, Ş., Kılıç Çakmak E., Akgün, Ö. E., Karadeniz, S. \& Demirel, F. (2013). Scientific Research Methods. (15. 
Press). Ankara: Pegem Publishing House.

[61] Ceyhun, A. T. (2009). Job stress, perceived social support and job satisfaction in teachers working with mentally retarded children. Unpublished MA Thesis. Bolu Abant İzzet Baysal University, Social Sciences Institute.

[62] Taşdan, M. (2008). The congruence level between personal values of teachers and organizational values of schools at public and private schools in Turkey, its relations with job satisfaction and perceived social support. Unpublished Ph.D. Dissertation. Ankara University, Educational Sciences Institute.

[63] Özkan, Y. (2005). The effect of teachers' organizational commitment in organizational socialization process. Unpublished MA Thesis. Ankara Gazi University, Educational Sciences Institute.

[64] Erdaş, Y. (2009). How the organizational commitment level of the teachers who works at the primary schools within the city center of Denizli is. Unpublished MA Thesis. Denizli Pamukkale University, Social Sciences Institute.

[65] Kul, M. (2010) The relationship between school administrators' leadership style and physical education teachers' exposure to mobbing, organizational commitment and job satisfaction. Unpublished Ph.D. Dissertation. Ankara Gazi University, Educational Sciences Institute.

[66] Uygur, M. (2010). The relationship between realization level of cultural leadership roles of primary school administrators and organizational commitment of the teachers. Unpublished MA Thesis. Konya Selçuk University, Educational Sciences Institute.

[67] Yüce, S. (2010). A research on relationship of instructional leadership behavior of elementary school principals and organizational commitment of teachers. Unpublished MA Thesis. Ankara Gazi University, Educational Sciences Institute.

[68] Erdogan, B., Kraimer, M. L. \& Liden, R. C. (2004). Work value conruence and intrinsic career success: the compensatory roles of leader-member exchange and perceived organizational support. Personnel Psychology, 57(1), 305-332.

[69] Duran, V. (2017). Curriculum Development Models, Different Logical Approaches and Complex System, svii. Mantık Çalıştayı Kitabı, Mantık Derneği Yayınları İstanbul. 